\title{
Sundanese and Modernity in Sci-fi Comic (Case Study:Astahiam Nyasab series of Sundanese Magazine Mangle in 1986)
}

\author{
Mohammad Isa Pramana Koesoemadinata ${ }^{1}$ \\ ${ }^{1}$ Facultyof Creative Industries, Telkom University, Bandung \\ 1dronacarya@yahoo.co.id
}

\begin{abstract}
Academic discourses and researches on Sundanese illustrations have already flourished, while there is still very little on Sundanese comics. Sundanese comics are more often available as insertions in Sundanese-language periodic printed media (magazines, newspapers) rather than standing alone (book, graphic novel). The discussion of Sundanese comics is still limited to the horror and mystery genres, while most others are based on folklore and daily life. Although it is very rare, there is also science fiction genre, including Oesnara's series of Astahiam Nyasab(1986) which was published in Manglemagazine.Oesnara's works are well crafted, semi-realist, detailed,expressively dynamic as well as unexpected plot besides being very humorous. The series shows the Sundanese people's traditional life but simultaneously displays metropolitan atmosphere with sophisticated technology and iconic popular cultural objects. These contrasting scenes interact each other humorously without any explicit conflict.This qualitative research using post-structuralism approaches, the object will be examined from aesthetical perspective, analyzed with the Art Critic method, and then dissected with hybridity theory, also cross-checked with several Sundanese cultural discourses. The conclusion is that this comic series shows how 1980s Sundanese people responded humorously to modernity and technology, their typical attitude that is still relevant today.
\end{abstract}

Keywords: Sunda, comic strip, science-fiction, parody, hybridity

\section{INTRODUCTION}

Sundanese illustration as the study theme has been raised by cultural observer and academician Hawe Setiawan, and has also been summarized in a series of writings entitled Olah Rasa Ilustrasi Sunda (2017) compiled by academicians of the Faculty of Arts and Literature of Universitas Pasundan of Bandung[1]. The most recent arethesis and dissertation researches by Kankan Kasmana from DKV UNIKOM of Bandung, specific about Sundanese horror comicthat has beenbroken down into a number of journal articles[2]. Other discusses the contemporary online 'Sundanese comic' entitled Komiklieur (2018), conducted by Patra Aditia from DKV FIK Telkom University [3].Apart from those, there are still very few specific discussions about Sundanese comics. Perhaps due its limited distribution, only available as comic strips, or also considered less significant in the development of Indonesian comics. 


\subsection{The Definition of Comic}

Comic is a kind of popular art which consists visual elements (character, property and setting visualisation, typography and baloon, also paneling)and non-visual elementsalso (textual narration, characterization, plot), which are arranged into a sequential narrative. Those elements correlated and supportive to each others, and characterisation as the main aspect is the conjunction of both, which is the key to success. There are various ways of character depiction, from the most realistic to most distorted (cartoon) manner. Character's physical depiction often made specifically to suit particular character. So, character depiction is made to be unique and significant, as according to Scott McCloud, the good characterisation must have particular psychological, distinguishable and expressive traits[4].Visual depiction of character is an expression of comic artist's idea, regarding context of the story which is presented.

\subsection{Sundanese Comic: 'The Definition'}

Similar tothe Sundanese illustration, there is no clear definition about Sundanese comic. Here the author try to draw the line that Sundanese comic is a comic which originally made and presented in Sundanese language, including the ones which inserted in Sundanese language magazine, while Sundanese-translated foreign comic and which mainly using Bahasa Indonesia and using Sundanese language occasionally, doesn't count as 'Sundanese comic'.Traditionally, Sundanese visual art was almost absent. Old Sundanese manuscripts (which are rarely found) didn't show that phenomenon, unlike old JavaneseBabad (historical) andPawukon (almanac) manuscripts which all are illustrated with wayang imageries. 'Sundanese visual art' emerged in accordance to the arrival of modern printing and publishing media, like school textbooks, magazine and newspapers. And the referred one here is Western-styled drawing, which is visualized all in naturalistic manner [2][5].

\subsection{Science Fiction (Sci-fi) Genre}

The natural landscape and horror theme has already identical to Sundanese, but not with science fiction (sci-fi). Sci-fi is a popular culture genre which mostly using scientific terminology or heavily inspired by scientific discoveries or technological inventions, either in ideas, theories, concepts or products. In the movies, it is tightly related with futurism, spacetime travel, scientific experiment, alien invasion, or even Earth's catastrophe [6]. Mendlesohn referred this genre as always being in-between of literature standard and commercial standard. It contains fantastic entertaining elements which developed into story plot formula until causing sci-fi into a significant part of popular fictions, such as romance, mystery and detective.Asci-fiwriter and critic, Aldiss defines this genre tentatively as an effort to search for the definition of human beings and their status in the universe amid scientific advances and confusion[7].

There is an impression that the traditional ethnic discourse is distanttoscience and technological sophistication as the icon of modernity. Science itself indeed was not from our culture. It is an element which is attached as a modern identity, born from the Western world. Historically, modernity has tended to be related to the changes of European society between the $16^{\text {th }}$ and $18^{\text {th }}$ centuries, like the change in the traditional socialorder into more modern, urban, industrial and democratic, characterized by the scientific and technology application in 
various aspects of life. According to August Comte, modernity is characterized by several new social orders in particular: urban life - centered; the application of science and technology in the production process (daily); the development of inequality and social gap[8].

\subsection{Hybridity in Sundanese Society}

Based on Mikhail Bakhtin's theory, Yasraf Amir Piliang states that hybridity is expressed as a new identity, the result of a dialogue or negotiation between many cultural elements that are contradictory. We can detect the existence of multiple codes, a combination of tradition and modernity [9]. This is clearly happening in Indonesia, especially in the Sundanese society in the cosmopolitan city of Bandung.Today's Sundanese society, like most other Indonesian ethnics, can be considered a hybrid society. On the one hand it has lived in a modern way, but in many ways pre-modern values rooted in the Sundanese traditions are still adhered to. There are characteristics of Sundanese people who tend to easily adapt to the changes and developments of the times, like the use of modern media.

It is not a surprise if Sundanese people use modern media such as comic with naturalist style, it also presents a combined story of jurig (ghost) myths as well as sci-fi icons, the results of which are actually comedy. Hybridity does not always produce something riveting, if it is not proportional and forced, it will produce parody. This parody is one of the characteristics of contemporary art tendencies in postmodernism and also oftenly used to present an impression of humor.This tendency is inseparable from the characteristics of the Sundanese themselves, as explained by Ajip Rosidi [10]. We can see that the archetype of the nature of the Sundanese can be divided between ideal nature and humorous nature. The ideal version can be obtained based on folklore stories such as pantun, for example Prabu Siliwangi, Mundinglaya in Kusumah and Si Sangkuriang, while the witty and even self-criticized version of Si Kabayan and Cepot folklore from the wayang story. The latter two characters, seem silly but satirical and make fun of the situation, without noble ideals or think much further, assume a relaxed and easy life, laugh at anything, but can be tricky when facing problems[10].

This is also a form of creativity, as a cultural survival strategy, as well as an expression of certain attitude statements. Although this was made in the 80 s comic series, it seems that this kind of creative strategy will not be outdated until now. This humorouscharacteristics, are reflected in Sundanese comedy works, as in the comics examined in this paper.

\section{METHODS}

This is a qualitative research, with a visual artwork (comic art) as the object, using the Art Critic as the primary analysis method, based on Edmund Burke Feldman's theory of Aesthetic Morphology[11], and supported by several other theories and discourseslike Mikhail Bakhtin'sHybridityaccording to Yasraf Amir Piliang's interpretation, and characteristics of Sundanese people according to Ajip Rosidi, Sundanese cultural observer, all related to Cultural Studies.

The comic objects taken as samples were the Astahiam Nyasar (Astahiam Lost) series, which was published in the Sundanese magazine Mangle from issue \#1043 (May, $8^{\text {th }}-14^{\text {th }}$, 1986) to \#1062 (September, 25 ${ }^{\text {th }}-$ October, $\left.1^{\text {st }}, 1986\right)$ all 21 episodes, scanned in digital file format from the personal collection of the late Mr. Haryadi Suadi at Kiaracondong, Bandung. Those was created by Oesnara, sometimes with 'Oe' only. However, due everything about the comic artist is unknown, even the editor of the Mangle itself does not have the archives, the discussion will use a post-structuralism approach, by considering a work as a text 
that has been launched to the public, then it belongs to the public, and is free to be interpreted based on other people's perceptions, regardless of the original intention of the creator.

\section{RESULT AND DISCUSSION}

\subsection{The Synopsis of Astahiam Nyasab (Astahiam Lost)}

The series tells the fantastic adventure of Astahiam, a simple man, living in a small alley (written as 'Gang Kiaracondong') in the urban slum with his wife and two children. One day he was picked up by an American from Greenpeace, asked for his willingness to fill an international conference on natural conservation. On his flight, the plane was hijacked, and Astahiam was thrown out after deflecting an enemy missile with hiskopeah (Malay hat).

Astahiam made an emergency landing on a remote tropical island inhabited by primitive tribes (whose familiar with the Indonesian police bureaucratic style) and would be sacrificed to the deity in the form of a giant statue of Semar. Astahiam managed to escape with a sexy female astronaut (Si Nok) who took him into space tracking the legacy of Nini Anteh on a satellite near the moon, which had already been claimed by the Americans since the landing of Apollo 11. The woman asked him to marry her, but Astahiam refused because he missed her family. So Astahiam went alone using a small spacecraft to Earth. On his way Astahiam was abductedby aliens and taken to an asteroid controlled by Uyut Ulu, an alien elder who was scolding American and Russian astronauts for their arrogance in exploiting the ecosystem for war. Surprisingly, Astahiam and Uyut Ulu turned out to know each other well, and Uyut Ulu repatriated Astahiam using the Challenger space shuttle to Earth.

When he returned to his country, it turned out that the airport Astahiam was headed for was controlled by armed militia in the form of humans with pig head, who then ambushed Astahiam's shuttle. Thus the story ends here, in a 'cliffhanging' state.

\subsection{The Visual Style of Astahiam Nyasab}

This comic is drawn in semi-naturalistic manner, strong in body proportions, body language, as well as facial expressions. The main character is depicted by the stereotypical Sundanese proportion, while some female characters are deliberately made withCaucasian photo model's body proportions. The body poses are drawn in various ways, very dynamic, even excessive and caricatured.Sharp lines and expressive strokes are the characteristic here. It seems that the artist used drawing pen since many lines and cross shading techniques, and also might berugos. The use of massive black ink block builds a strong three-dimensional spatial impression. Quite detailed in properties (buildings, tools, vehicles, traditional and modern clothing).

This realistic style and details reminds us of the legendary Sundanese illustrator the late Onong Nugraha. Onong's visual features are black and white which includes combination of black blocks, shading, and images that are all natural-realistic, shown by mastering the details of anatomy with naturalistic proportions, natural gestures or body language, depictions of body silhouettes, not to mention depicting detailed properties and the surrounding environment such as trees and natural scenery [1][5]. This style is rarely found in the other Sundanese comics. 

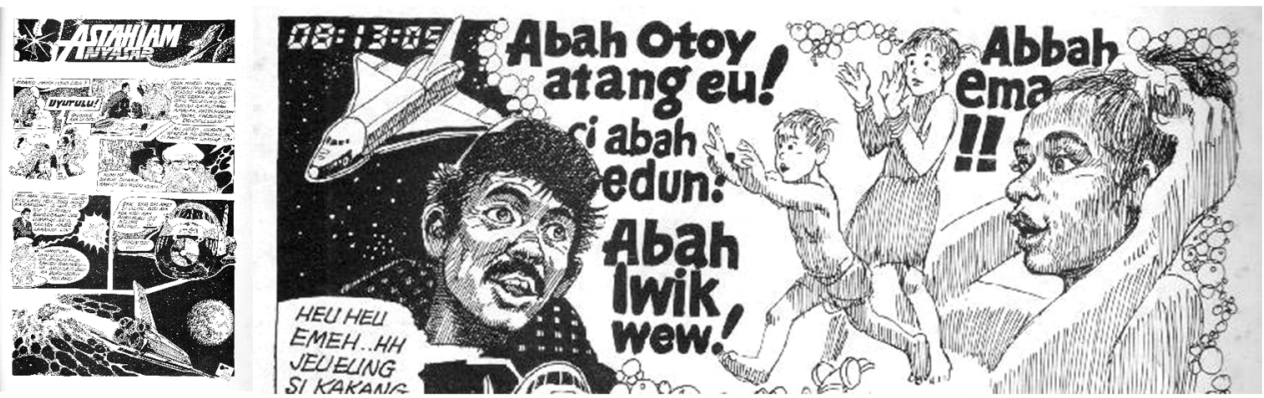

Figure 1. Page samples of the comic strip seriesAstahiam Nyasab (Mangle, 1986); the depiction of the figure of Astahiam with his wife and children.

\subsection{Depictions of Characters, Properties and Settings}

Astahiam's figure is portrayed as a stereotypical Sundanese peasant, with a mustache, buheukeu (short stocky) body, bent posture, with iconic attributes of the late Sundanese comedian Kang Ibing (kopeah, sarong, sontog pants), with facial expression resembles the Cepot character of Sundanesewayang golekpuppet show, which looks innocent, simple, clownish but often cunning and resourceful.Emeh (wife) is depicted as a peasant woman, with strings of hair tied up, dressed only bra and kain. Showing a housewife who is often at home taking care of children so that not much dressing, yet often displays sensual gestures to her husband. Iwik (daughter) a little girl with two braided hairs above the ears. Otoy (son), a toddler who is often shown to have slipped or naked pants, still unaware of manners. Both are very active and wayward. Their appearance characterizes as if left unattended or neglected.

Jeans Swaartchzeichentusche, a Caucasian from Greenpeace, tall, blond, long nose, dressed in ethnic-ornamented clothes, shorts, wearing a camera like a tourist. Caricatured, by exaggerating certain anatomical parts, stereotypes of foreign tourists in Indonesia. Aircraft hijackers, depicted in the stereotypical style of secret agents or gangsters in Hollywood detectiveand cartoon movies, wear fedora hats, shades, and long trench coats with collars covering the neck.'Si Nok', a female astronaut described as beautiful, tall, short-haired, paramilitary dressed, and has a smart and decisive impression. Described ideally with Western female anatomy. Her appearance resembles the tomboyish female characters in Hollywood movies. The primitive tribes who inhabited the island has pre-historic man faces, half-naked, exotic, typical inland tribes in Hollywood perspective. It was funny because they had a 'bureaucracy' in treating prisoners and offering cigarettes to Astahiam during interrogation.Uyut Ulu, an alien elder who abducted Astahiam, was shown to be round, with bald head larger than the body, with a thick beard that covers the body. He gave impression of an old man who is drawn all deformities, hot-tempered yet wise. His alien followers are described as short and insect-like.

The modern vehicles displayed there are unavailable in Indonesia [12]. The depiction of modern military properties similar to American and Russian seems to be inspired by the Hollywood action movies (Commando, Rambo, Top Gun, and Iron Eagle) at that time. Also various hi-tech, futuristic and fantastic properties were inspired by the sci-fi and space adventures shows (Star Trek, Aliens, and Buck Rogers), both on TV, cinema and video cassettes. It was also supported by a lot of military technology coverage in various printed media complete with photo illustrations (Angkasa magazine, youth magazine Hai) at that time. This is inseparable from the Cold War between the Western Bloc (United States) against the Eastern Bloc (Soviet Union), where there was a race of military technology between both 
sides (President Ronald Reagan's Starwars program), and the conflict between Iran-Iraq at that time. Indonesians, especially urban Sundanese, are becoming witnesses and spectators to those. News was so widespread, both in the mass media such as newspapers and television, as well as in various popular media including works of fiction such as movies and so on.

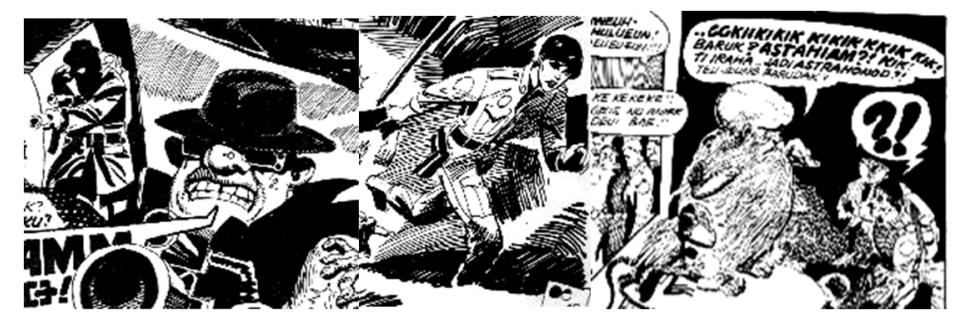

Figure 2. Other characters: the hijackers, Si Nok and Uyut Ulu

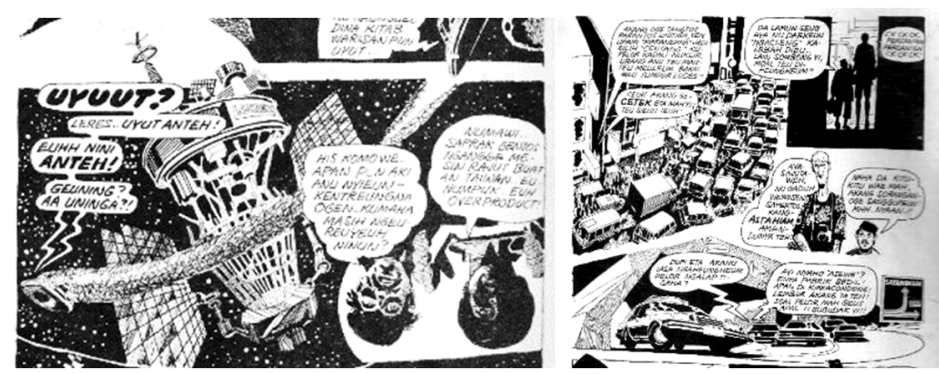

Figure 3. Panels that display sophisticated hi-tech properties such as space satellite, and metropolitan city-style traffic jam in Bandung

The setting of the city where Astahiam lived (possibly Bandung, due 'Gang Kiaracondong' text) was shown with many tall buildings, highways and traffic jams (like Bandung in 2000s). While the urban slum alleys of Astahiam's residence are narrow, messy, shabby, disheveled and dark. Full of clothesline, signposts, billboards and directions, besides crowds of people around.

\subsection{The Discussions}

Many modern elements were being featured in the Astahiam Nyasab. Metropolitan view, traffic jam, military aircrafts, sexy female astronaut, spacecraft, and aliens. For 1986, this was very 'sophisticated', because it showed contrast scenes simultaneously and not in conflict, while also making a tweak. The hybrid combination of various different features in one story, traditional Sundanese icons appear together with the hi-tech stuffs in the style of sci-fi, clearly makes a very silly and absurd impression. The impression is arbitrary even chaotic, just to show the artist's spontaneity, who was clearly playing with the reader, is just a Sundanese style of humor. It is true that most of arbitrary hybridity results in parody, but simultaneously also gives us something new and fresh. This comic is also 'visionary' because it is as if some of the conditions presented are predictions in the future (from that time), and have been proven today, so it is still very actual for the present. It would be very unfortunate if such minor views yet smart, predictive, and witty are ignored.As a comic artist, Oesnara definitely was very rich with references, based on daily observations and various sources, as well as references to his visual style. Having a wild and eccentric creativity, he was able to produce an 
intelligent form of humor that was smart, witty and satirical. Even today, the 'Sundanese comics' are still based on humor, just like Komiklieur. This trait is indeed inherent and will continue to be Sundanese identity in the future, as a creative strategy.

This paper has brought different observable, analyzable and discussable aspects from the usual in other researches on Sundanese fictions. Spirituality, humor, horror and daily life, all have been discussed, including in Kasmana's research about Sundanese horror comics, or Aditia's paper on humorous Komiklieur. So, this paper gives us new perspective to look Sundanese cultural discourse, which is about hybridity.

\section{CONCLUSION}

That is all this paper can discuss, due the research is still a preliminary and limited only to a few samples. Hopefully that in the future there will be more research and discussion on other Sundanese comics more thoroughly, in various genres and styles, past till recent period, more detailed and in-depth. All of which will give us a more holistic and complete picture, how modern Sundanese people express themselves through popular media, especially visual comics.

\section{ACKNOWLEDGEMENTS}

The author gives his profound gratitude to Dr. Kankan Kasmana (UNIKOM, Bandung) and Mr. Radi Arwinda, son of the late Mr. Haryadi Suadi(Kiaracondong, Bandung) for sharing the comic archival documentation and Mangle magazines, as well as for a series of discussions.

\section{REFERENCES}

[1] H. Setiawan and I. S. Ibrahim, Eds., Olah Rasa Ilustrasi Sunda. Bandung: UNPAS Press, 2017.

[2] K. Kasmana, S. Sabana, I. Gunawan, and H. A. Ahmad, "The Sundanese Comic Ririwa Nu Mawa Pati - An Intertext of Sundanese - Islam Cosmology,” Mudra J. Seni Budaya, 2018.

[3] P. Aditia, "REPRESENTASI KARAKTERISTIK ORANG SUNDA DALAM KOMIKLIEUR,” J. Ilm. LISKI (Lingkar Stud. Komunikasi), 2018.

[4] M. I. P. Koesoemadinata and D. K. Aditya, "Visualizations of Wayang Characters in Comics (Case Study: Bima and Arjuna Characters in the Arts of Ardisoma, Teguh Santosa and Is Yuniarto)," in 3rd Bandung Creative Movement Proceedings, 2016.

[5] H. Suadi, Onong Nugraha: Sebuah Riak dalam Gelombang Sejarah Seni Ilustrasi di Indonesia. Penerbit Dewan Kesenian Daerah Jawa Barat, 2000.

[6] S. Tjipto R, "PERJALANAN FANTASI MENEMBUS RUANG DAN WAKTU (Analisis Semiotika Film The Time Machine)," REKAM J. Fotogr. Telev. dan Animasi, 2016.

[7] F. Merawati, "Perkembangan Fiksi Ilmiah Karya Pengarang Indonesia Tahun 1980-an dan 2000-an Pendidikan Bahasa dan Sastra Indonesia," Gramatika J. Ilm. Kebahasaan dan Kesastraan, 2015.

[8] Irfansyah and Y. A. Piliang, "Perbandingan Kode Visual Pertunjukan Golek Sunda Tradisional dan Pertunjukan Golek Sunda dalam Media TV," Panggung, 2013.

[9] Y. A. Piliang, Medan Kreativitas: Memahami Dunia Gagasan. Yogyakarta: Penerbit Cantrik Pustaka, 2018.

[10] A. Rosidi, Manusia Sunda, 3rd ed. Bandung: PT Kiblat Buku Utama, 2009.

[11] M. Isa Pramana Koesoemadinata, "Visual Adaptation Of Wayang Characters In Teguh Santosa's Comic Art,” Mudra J. Seni Budaya, 2018.

[12] K. Saddhono and S. Supeni. "The role of dutch colonialism in the political life of Mataram dynasty: A case study of the manuscript of Babad Tanah Jawi." Asian Soc. Sci. vol. 10 no.15 pp. $1-7,2014$ 
